\title{
One Stay Three Stray in Teaching Reading
}

\author{
Maghfirotul Baroroh \\ Universitas Muhammadiyah Jember \\ (maghfirohbaroroh@gmail.com)
}

\begin{abstract}
This research aimed to know whether one stay three stray method can improve students' reading comprehension at SMA Muhammadiyah 3 Jember in 2017/2018 academic year. The type of this research was Classroom Action Research (CAR). This research was done in two cycles which consisted of planning, implementing, observing, and reflecting in each cycle. The subjects of this research were the students 32 students of tenth Science at SMA Muhammadiyah 3 Jember. The research instruments used were reading test and observation checklist. The result of reading test data in cycle 1 showed that the students did not achieve the criteria of success. The researcher needed to revise lesson plan or strategy in cycle 2. All activities were done with the balance partner and having two clockwise around the room. Based on result of data analysis there was improvement on students' reading comprehension which can be seen from the results of the two cycles in which cycle 2 was better than cycle 1.
\end{abstract}

Keywords: Reading comprehension, one stay three stray method.

Reading is one of the skills taught in senior high school level not to mention other skills such as listening, speaking and writing as well. As its important role in learning, reading has its role as a means to understand English texts and other English written sources of learning.

Reading as one of the four language skills is an essential skill for the students at every level started from elementary school until university. Through reading, the students are expected to be able to connect what they have and how meanings are made from the text, which means they not only get information or knowledge, but also enjoyment as well (Garllett, 1996:4).

In researching about reading comprehension, the researcher conducted a preliminary study which was conducted on April 14th 2018 at SMA Muhammadiyah 3
Jember. She interviewed the English teacher who taught the $\mathrm{X}$ grade students to get the information about the reading score of the students. From the result of the preliminary study, it was found that the X grade students of SMA Muhammadiyah 3 Jember got difficulty in understandig the text and the sentences well. The average score of the students in reading class was $\leq 75$. There were 12 students who got score $\geq 75$ and 20 students who got score $\leq 75$. From the interview, it was concluded that the $\mathrm{X}$ grade students had problems in learning English, especially with their reading skill. The teacher informed that their problem was that they could not comprehend the text for their lack of vocabulary. This has caused them to be time consuming in understanding the text. Therefore, it led them to have problems in making conclusion about the content of the text. Besides, it was difficult for them to 
comprehend the sentences in the text since they were unable to denote the meaning of the sentences. What they were able to was the broad outline of the content. It means that they could only comprehend the general meaning of the text without understanding the detail content of the texts.

Those problems has led the researcher to employ one stay three stray method to improve students' reading comprehension.

Crawford (2005: 63) proposed are some steps to implement one stay three stray method. The steps are as follow:

1 . The students are assigned to home groups of four.

2. Making a clockwise around the room, the teacher numbers the tables.

3. The students are assigned a question to discuss, or a task to perform.

4. After they have worked on the task for an interval perhaps 15 minutes, the teacher asks everyone with the number one to stand up, move one table to the next numbered table (from table one to table two, from table two to table three, and so on).

5. Once the students with number one have moved, the teacher asks those with number two to stand. They should move from table one to table three, from table two to table four, and so on. Those with number three move three tables: from table one to table four, and so on. Those with number four should stay at their original table.

6. The teacher asks the students who are visiting each table to interview the remaining members from the original group to find out how that group answered the question. They should take notes and prepare to take them back to their own table.

7. After five to eight minutes, have everyone goes back to their original group and report on what they learned from the other tables. Each student should take three minutes to report on what they learned.

In the $\mathrm{X}$ grade class of SMA Muhammadiyah 3 Jember, there were 32 students. To implement one stay three stray method, the students were divided into 8 groups with 4 students for each group to be participated in the teaching and learning process.

\section{Method}

This research employed a classroom action research (CAR). The CAR was based on Kemmis and Mc Taggarat's design (See Figure 1). The research subjects were the tenth grade students of SMA Muhammadiyah 3 Jember in the $2017 / 2018$ academic year, especially class X IPA 5 which has 32 students.

Based on the research design, the actions of the research were implemented in four stages. According to Lewin in Arikunto (2010: 131), Classroom Action Research (CAR) consists of four stages in each cycle. Those are planning, implementing, observing and reflecting. The planning stage was when the researcher prepared the lesson plan and the instructional material. The second stage was implementing the action. The researcher implemented or conducted the plan in teaching learning process. The next stage was observing. The researcher observed and analyzed the key issues related to the problems identified in implementation stage. Observing was done during teaching and learning process. Finally,

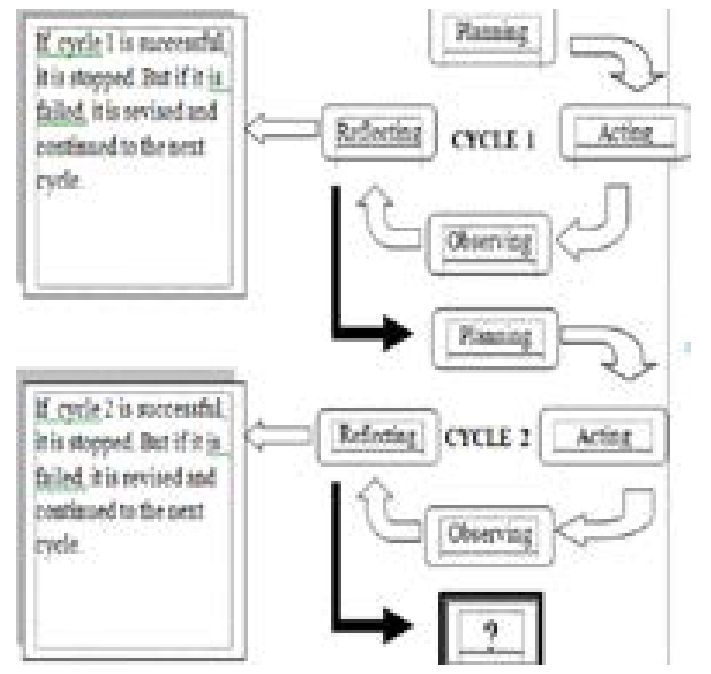

Figure 1. The Cycle of CAR 
the last step was reflecting. It was conducted to identify what were the problems in conducting the method.

In this research the instruments employed were reading test and observation checklist. The researcher employed content validity to get the primary data. In this case, the validity of the test was made by constructing the test item based on the indicators in the curriculum.

\section{Results and Discussion}

The reading test in cycle I was held on 27th April, 2018 to know how far students improvement in reading comprehension after implementing the action using one stay three stray method. The reading test was conducted to measure the students' word comprehension, sentence comprehension, paragraph, comprehension, and $\mathrm{te} \times \mathrm{t}$ comprehension. The material used was narrative text. From the test result in cycle I, the mean score of the students reading comprehension using one stay three stray was $44 \%$ or 14 of the whole students who got $\geq 75$. It was considered to be not successful yet as it hasn't covered $75 \%$ of students to reach the minimum standard of success which was required to have score $\geq 75$. Therefore,

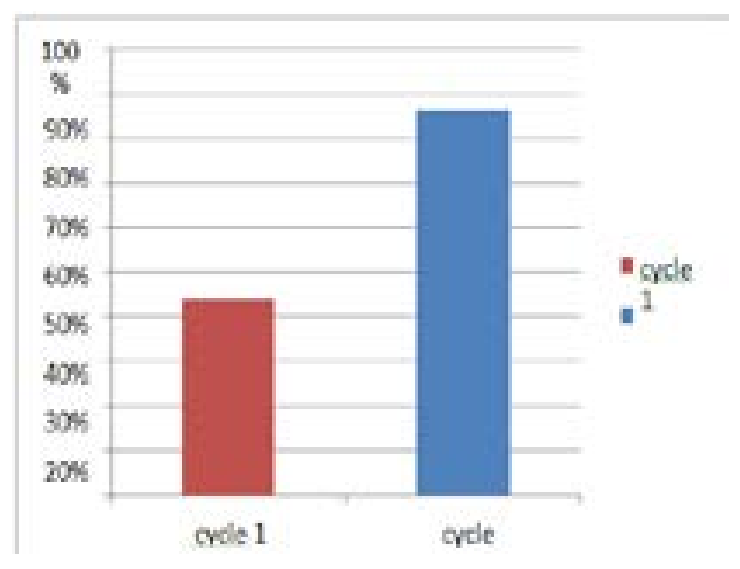

Figure 2. Percentage of Students' Reading Test Result the researcher planned some activities in the second cycle in order to be successful. She provided vocabulary list and made two clockwise around the room. In addition, she also grouped the students with the balance partner which means that each group has members with mix capability. A test was taken after the action done in cycle II.

From the result of reading test in cycle II, the mean score was 79.06 and the percentage of students who got the standard mean score was $86 \%$. It means that the minimum standards mean score $\geq 75$ and the percentage requirement of reading comprehension of $86 \%$ has been able to be reached. Therefore, it can be said successful. The different percentage could be seen in Figure 2 .

The reading test result of cycle 2 showed that the students' reading score has been improved compared to cyclel.It can be seen from figure 1 that there was an improvement from cycle 1 to cycle 2 . The modification of the grouping by grouping students with mix capability could cover the cycle 1 which was failed to improve reading comprehension using one stay three stray method. As Dotson (2004) stated that heterogeneous grouping of students is essential to the use of cooperative learning structures and the groupings involved consisting students with varying abilities.

So, grouping students with mix or varying abilities can assist them to have a group sharing among each members to find the information of the text.

Employing one stay three stray can improve students' reading comprehension. It was also supported by the previous research conducted by Destyawarni (2015). It revealed that One Stay Three Stray can give opportunity to group members to exchange ideas to comprehend a reading text. Thus, this technique can help students in learning material more easily, in this case comprehending the narrative text. It is Also in line with Hapsari (2014) which resulted that One stay three stray become one of the most valuable tools educators have to develop students' activeness in academic. In 
this case, the students were more active in completing the tasks they had with the English text, not only to sit still, instead, they were required to seek information from the other students in different groups and shared what they have found with their group.

Here the dynamic atmosphere of learning has emerged and reading was no longer a passive skill in learning a language, especially English.

\section{Conclusion}

One stay three stray can improve students' reading comprehension by creating cooperative learning environment through sharing information about the content of the text from one group to another group at SMA Muhammadiyah 3 Jember in the 2017/2018 academic year. Considering the result, some suggestions are addressed to the future researchers who plan to employ one stay three stray to always control the time. Make sure the time for sharing information from group to group will be too long since the teaching allotment for the subject was only for 90 minutes.

\section{References}

Ali, H. Muhammad. (1993). Strategi Penelitian Pendidikan. Bandung: Angkasa

Arikunto, Suharsimi. (2013). Prosedur Penelitian. Yogyakarta: Rineka Cipta. (2006). Prosedur Penelitian Suatu Pendekatan Praktik. Jakarta: PT Rineka Cipta.

. (2014). Prosedur Penelitian: Suatu Pendekatan Praktik (Cet. 15). Jakarta: PT Rineka Cipta.

Ary, Donald. (2010). Introduction to Research in Education (8 ${ }^{\text {th }}$ Edition). United State
Carrel, P. L., J. Davies, and D. E. Eskey. (1988). Interactive Approaches to Second Language Reading. Cambridge: Cambridge University Press.

Crawford. (2005). Teaching and Learning Strategies for the Thinking Classroom. New York: The international Debate Education Assosiation.

Destiyawarni, Endang S., Wardah. (2015). The Use of Two Stay-Two Stray In Teaching Reading Comprehension On Narrative. Jurnal Pendidikan dan Pembelajaran, 4(2) 1-11.

Dotson, M., J. (2001). Cooperative Learning Structures Can Increase Student Achievement. San Clemente, CA: Kagan Online Magazine.

Fisher. (2000). Narrative Text. Geelong Australia: Deakin Univerisy Press.

Gillingham, M. G. (1996). Cognitive Aspects of Electronic Text Processing. USA: Ablex Publishing Corporation.

Grellet, F. (1996). Developing Reading Skills. Cambridge University: Cambridge University Press.

Hannah, Alie. (2009). Reading Comprehension: Nature, Assessment and Teaching. ESRC.

Hapsari. I. P. Novia T., Galuh K. D. A. (2012). One Stay Three Stray: Strategi Meningkatkan Ketrampilan Menulis Jenis Teks Eksposisi Dalam Pembelajaran Genre-Based Writing. Jurnal Penelitian Pendidikan, 30(1), 43-50.

Hogue, Ann. (2008). First Steps in Academic Writing ( $2^{\text {nd }}$ Edition). United States of America: Pearson Education.

Hughes, Arthur. (1989). Testing For Language Teachers. New York: Cambridge University Press.

Kagan, S., \& Kagan, M. (2009). Kagan Cooperative Learning. California: Kagan Publishing. 
McNamara. (2007). Reading Comprehension Strategies. New York: Psychology Press.

Morris, Michael. (2007). An Introduction to the Philosopy of Language. New York: Cambridge University Press.

Purwanto, M. N. (1992). Prinsip-Prinsip dan Teknik Evaluasi Pengajaran. Bandung: Remaja Rosdakarya.

Siahaan, Sanggam. (2008). The English Paragraph. Yogyakarta: Graha Ilmu.

Patel and Jain. (2008). English Language Teaching: Method, Tools, and Technique. New York: Sunrise Publisher and Distribution.

Willis, Judy. (2008). Teaching the Brain to Read: Strategy for Improving Fluency, Vocabulary, and Comprehension. United States of America: Assosiasion for Supervision and Curriculum Development (ASCD). 